\title{
Investigating the Relationship Between Employees' Perceptions of Organizational Justice and Social Capital in The National Tax Administration in the South of Tehran Province
}

\author{
Seyyed Meysam Hosseini
}

Master of Public Administration, Firoozkooh Branch, Islamic Azad University, Tehran, Iran

\section{*Corresponding Author: \\ $\sim$ Hosseini.s.m@gmail.com}

Received: 15 February, 2021

Accepted: 30 March, 2021

Published: 25 April, 2021

\begin{abstract}
This study aimed to investigate the relationship between employees' perception of organizational justice and social capital in The National Tax Administration in the south of Tehran province. This is an applied study in terms of purpose, descriptive in terms of nature, and survey in terms of method. The statistical population included all employees of the National Tax Administration in the south of Tehran province. According to Morgan and Krejcie's table (1990), 214 people were selected as the sample size in simple random sampling method. Talebzadeh Organizational Justice Questionnaire (2011) and Kennedy Social Capital Questionnaire were used to collecting data. The research hypotheses were examined to analyze the data using the Pearson correlation coefficient test. The study results showed a positive and significant relationship between employees' perception of distributive justice, procedural justice, interactional justice, information justice, and the total score of organizational justice with the social capital.
\end{abstract}

Keywords: Organizational Justice, Distributive Justice, Procedural Justice, Interactional Justice, Information Justice, Social Capital

\section{Introduction}

In recent years, it has been much attention to the issue of organizational justice and its effects on organizational results and led the organizations to use different models and methods to achieve their goals and gain a new competitive advantage to avoid fall, overturns and risks resulting from rapid environmental changes [1]. Today, achieving the organization's goals depends mainly on the proper and correct performance of the employees, and the organization's efficiency has maintained its close relationship with the categories of organizational justice and social capital.

Justice is a concept intertwined with society and is present in most aspects of life. It is common to believe that the consequences of everything should be accompanied by justice [2]. Justice is one of the glorious and inseparable heritages of humanity that has formed the foundation of human rights. In the contemporary world, justice is a missing link that has often affected human rights activities. Theories of justice have evolved in parallel with the expansion and development of human society, and its range has extended from the theories of religions and philosophers to empirical research. After the Industrial Revolution and the mechanization of human societies, organizations have dominated human life to such an extent that every human being is directly dependent on them from birth to death. Today, life is inconceivable without the existence of organizations. Therefore, people spend most of their lives in organizations or in relation to organizations, which shows the importance of the position of organizations in today's world [3].

Aspects of justice play a significant role in organizational life. As a result, it also finds meaning in the organization and is referred to as organizational justice [2]. Organizational justice is the degree to which employees feel that their work rules, procedures, and policies are fair [4]. In particular, employees' perceptions of equality and how they are fairly treated 
can affect other work-related variables [5]. The essential aspects studied in the field of organizational justice are distributive, procedural, and interactional justice. Of course, Kidder [6], Aydin \& Karaman-Kepenekci (2008) also introduce other concepts of organizational justice such as reform justice, information justice, and reconstructive justice [7].

Distributive justice means observing fairness when distributing results and consequences among the organization's employees [8]. Procedural justice refers to the processes and procedures through which decisions are made about allocating and distributing resources. Interactive justice, unlike procedural justice, includes fewer formal aspects of interaction (Amirkafi and Hashemi Nasab, 2014) [9]. Information justice is related to interpretations that provide the information needed to evaluate processes

Social capital is one of the variables that organizational justice can be related to.

Social capital is a form of capital that facilitates access to vital information and resources to improve performance and appropriate use of environmental opportunities [10]. An organization with substantial social capital can quickly access a diverse set of information with proper timing to create an innovative performance. This capital is a kind of intangible asset for organizations and, the most successful companies are those that use this asset in a desirable way and in the fastest possible time. Social capital increases performance through trust, participation, and cooperation among members [11].

In theoretical texts of social capital, it has always been emphasized the factors affecting its promotion. Researches show that sense of injustice has a detrimental effect on employees' morale and affects their behavior. If employees feel they have been treated fairly, they will be more motivated to perform better. Employees tend to be treated fairly and enjoy appropriate benefits based on the type of activity they perform and be promoted based on their competence, skills, and abilities [12]. Justice is done when everyone is treated according to their merits and abilities; justice in positions, appointments, fair pay, the exercise of authority, and decisions are the basic principles of meritocracy. Paying attention to meritocracy affects people's attitudes and beliefs and, as a result, will lead to greater employee productivity. Considering the vital role of social capital in organizations and according to the presented materials, the researcher examined the relationship between employees' perception of organizational justice and their social capital in the National Tax Administration in the south of Tehran province. Therefore, the present study seeks to investigate the following hypotheses:

- Examining the relationship between employees' perceptions of organizational justice and social capital
- Examining the relationship between employees' perceptions of distributive justice and social capital

- Examining the relationship between employees' perceptions of procedural justice and social capital

- Examining the relationship between employees' perceptions of interactive justice and social capital

- Examining the relationship between employees' perceptions of information justice and social capital

\section{Research Literature}

A) Organizational Justice

Transcendent organizations use, manage and develop all the potential of their employees at individual, group, and organizational levels. They promote justice and equality and involve employees in empowering them. They believe that one of the principles of organizational justice is paying attention to opinions, and participation in decision-making increases perceived justice [13]. The concepts of justice and fairness, which are also discussed in organizational environments and among employees, are generally referred to as organizational justice [14]. According to Bies \& Tripp [15], justice in organizations refers to the social rules and norms in the management of organizations and includes the following:

1 - How to allocate output in the organization

2. Procedures to be used for decision making

3- How interpersonal behaviors in the organization

This definition implies three dimensions for justice: distributive justice, procedural justice, and interactional justice.

Organizational justice refers to employees' perceptions of fairness and fair professional behavior. The study of organizational justice began with Adams' study (1963 and 1965) on the theory of equality, which emphasized the equity of consequences; Employees' perception of equitable distribution of consequences is called distributive justice [13]. Distributive justice exists when the distribution of organizational consequences, such as compensation for services, benefits, and rewards given to employees, is related to their input and activities in the organization. While distributive justice emphasizes consequences, procedural justice emphasizes the process that leads to results. Procedural justice is valuable because it ultimately leads to distributive justice. Interactive justice or interactional justice is based on the perceived fairness of interpersonal communication related to organizational practices and the quality of interpersonal communication. Interactional justice emphasizes that responsible individuals in the organization allocate resources and rewards in the workplace according to the recipients' behavior [16].

B) Social Capital 
The term social capital was first coined before 1916 in an article by Hanifan from the University of West Virginia. However, it was first used in the classic work of Jacobs (1961) entitled "The Death and Life of Major American Cities" [17]. In the 1970s, economist Glenn Loury and sociologist Evan Lighte used the term social capital to refer to a solution to the problem of urban economic development. Lowry used social capital theory to criticize the theological theories and the unfair distribution of income [18].

Bourdieu (1980) was the first to design and implement systematic research in social capital and introduced this concept as a theory. He has done a lot of research on the development of social capital and the benefits that come from it as a source of capital. James Coleman (1988) also introduced this concept to the political arena for the first time in North America, and Putnam followed his efforts at that time in Europe. The theory of social capital has practically evolved with Bourdieu, Coleman, and Putnam [19]

Jane Jacob defines social capital as social networks that have functions in society and are irreplaceable. These functions can lead to economic development in societies [18]. Peter Bourdieu defines social capital as the total of real and virtual resources that belong to an individual or group and are exercised by acquiring a relatively stable network of mutual acquaintance and cognition. Bourdieu believes that social capital is obtained from the communication and participation of members of the organization and can be used to achieve economic capital . Putnam considers social capital as a set of concepts such as trust, norms, and networks that create optimal communication and participation of community members and ultimately serve their mutual benefits. According to Brett, social capital is having friends, companions, and more general communication, giving the unique opportunities to use their financial and human capital [20].

Social capital includes three dimensions of structural capital, communication capital, and cognitive capital.

- Structural Capital: Structural capital refers to the general pattern of interpersonal contacts. Many aspects have been mentioned to introduce this dimension, the most important of which is network relations (creating information channels). Networking relationships with various groups, teams, organizations, and institutions leads to improved access to information and rapid response to changes and developments within and outside the organization [19].

-Communication Capital: The relational element of social capital expresses a kind of personal relationship that people establish because of their history of interactions. The most important aspects of the communication dimension are trust, norms, requirements, and expectations of role and identity [20].
-Cognitive Capital: The cognitive element of social capital refers to the source that provides manifestations, interpretations, interpretations, and systems of common meanings among groups. Cognitive capital is a reflection of the commitment and defense of team members of their purpose and mission. The most important aspects of the cognitive element are common goals, common language and codes, familiar anecdotes [21].

\section{Literature Review}

Siddiqui and Pouramini [22] examined the relationship between organizational justice and social capital (Case study: Tejarat Bank employees in Ardabil province) showed a positive and significant relationship between organizational justice and social capital.

Kheirandish and Jafarinia [23] studied the effect of organizational justice on promoting social capital through the mediation of meritocracy in the organization and showed that organizational justice affects the meritocracy through the social capital. Also, the direct effect of organizational justice on the promotion of social capital is equal to 0.39 , and its indirect effect through the mediation variable of meritocracy is equal to 0.5 .

Chavishni and Naghshbandi (2014) studied the relationship between organizational justice and the social capital of employees in Kurdistan Electricity Distribution Company and showed a significant correlation between organizational justice and social capital factor affecting employee productivity [24].

Buluc [25] study examining the relationship between faculty perceptions of organizational justice and organizational citizenship behavior showed a positive and significant relationship between organizational justice and organizational citizenship behavior of university staff.

\section{Method}

The present study is applied in terms of purpose and descriptive survey in terms of data collection. The statistical population includes all the National Tax Administration employees in the south of Tehran province, 475 people (363 men and 112 women) and 409 formal ones and 66 contractual ones who have been employed. According to the study's statistical population, 214 people (162 males and 52 females), 189 formal ones, and 25 contractual ones were selected through a simple random sampling method through Krejcie and Morgan table. Talebzadeh Organizational Justice Questionnaire (2011) and Kennedy Group Social Capital Questionnaire were used to collecting the data. The research hypotheses were examined using the Pearson correlation coefficient test to analyze the data and respond to the research hypotheses. 
A) The Kennedy Group Social Capital Questionnaire has 15 questions, and all three ones examine one dimension of social capital (trust, informal social communication, forgiveness, and volunteerism, socializing friendships, and civic participation); it is scored based on the Five-point Likert scale from strongly disagree $=1$ to agree $=5$ strongly. The reliability of the questionnaire in this study was obtained using Cronbach's alpha coefficient of 0.811 .

B) Talebzadeh Organizational Justice Questionnaire (2011), which has 25 questions and four components (distributive justice, procedural justice, interactional justice, and information justice) and in the form of a five-point Likert scale from none $=1$ to very high $=5$ is scored. The reliability of the questionnaire in this study was obtained using Cronbach's alpha coefficient of 0.899 .

\section{Findings}

In this section, descriptive data of the studied variables are presented to 214 employees of the National Tax Administration of South Tehran.

Examination of demographic factors of the statistical sample showed that among 214 questionnaires, 75.7\% were male (162 ones), and $24.3 \%$ were female (52 ones). The highest number was official employment at $88.3 \%$ (189 ones) based on the type of employment.

- Check the Normal Distribution of Data

The Kolmogorov-Smirnov test was used to test the hypothesis of normal data distribution.

Table 1

Status of data distribution of research variables

\begin{tabular}{lcc}
\hline Variable & Kolmogorov-Smirnov & Significance level \\
\hline Perception of distributive justice & $0 / 178$ & $0 / 125$ \\
Perception of procedural justice & $0 / 147$ & $0 / 117$ \\
Perception of interactive justice & $0 / 135$ & $0 / 113$ \\
Perception of information justice & $0 / 114$ & $0 / 111$ \\
Social capital & $0 / 119$ & $0 / 114$ \\
\hline
\end{tabular}

The results of Table 1 show that the statistical data had a normal distribution.

According to the normal distribution of data, the Pearson correlation coefficient was used to test the hypotheses using SPSS22 software.
Hypothesis 1: There is a significant relationship between employees' perceptions of organizational justice and social capital.

Table 2

Results of the correlation test of the first research hypothesis

\begin{tabular}{lccccc}
\hline & $\begin{array}{c}\text { Correlation } \\
\text { statistics }\end{array}$ & $\begin{array}{c}\text { Correlation } \\
\text { value }\end{array}$ & $\begin{array}{c}\text { Degrees of } \\
\text { freedom }\end{array}$ & $\begin{array}{c}\text { Significance } \\
\text { level }\end{array}$ & $\begin{array}{c}\text { Confirm or reject } \\
\text { the hypothesis }\end{array}$ \\
\hline $\begin{array}{l}\text { Employees' perception of } \\
\text { organizational justice and social capital }\end{array}$ & $0 / 907$ & $0 / 139$ & 212 & $0 / 000$ & Confirm \\
\hline
\end{tabular}

The results of Table 2 show that there is a significant and positive relationship between employees' perceptions of organizational justice and social capital concerning a significance level of less than 0.05 .

Table 3

Results of the correlation test of the second research hypothesis

\begin{tabular}{lcccc}
\hline & $\begin{array}{c}\text { Correlation } \\
\text { statistics }\end{array}$ & $\begin{array}{c}\text { Degrees of } \\
\text { freedom }\end{array}$ & $\begin{array}{c}\text { Significance } \\
\text { level }\end{array}$ & $\begin{array}{c}\text { Confirm or reject } \\
\text { the hypothesis }\end{array}$ \\
\hline $\begin{array}{l}\text { Employees' perceptions of } \\
\text { distributive justice and social capital }\end{array}$ & $0 / 434$ & 212 & $0 / 000$ & Confirm \\
\hline
\end{tabular}

The results of Table 3 show that there is a significant and positive relationship between employees' perceptions of distributive justice and social capital regarding a significance level of less than 0.05.
Hypothesis 2: There is a significant relationship between employees' perceptions of distributive justice and social capital.
Hypothesis 3: There is a significant relationship between employees' perceptions of procedural justice and social capital. 
Table 4

Results of the correlation test of the third research hypothesis

\begin{tabular}{lcccc}
\hline & $\begin{array}{c}\text { Correlation } \\
\text { statistics }\end{array}$ & $\begin{array}{c}\text { Degrees of } \\
\text { freedom }\end{array}$ & $\begin{array}{c}\text { Significance } \\
\text { level }\end{array}$ & $\begin{array}{c}\text { Confirm or reject } \\
\text { the hypothesis }\end{array}$ \\
\hline $\begin{array}{l}\text { Employees' perceptions of } \\
\text { procedural justice and social capital }\end{array}$ & $0 / 863$ & 212 & $0 / 000$ & Confirm \\
\hline
\end{tabular}

The results of Table 4 show that there is a significant and positive relationship between employees' perceptions of procedural justice and social capital regarding a significance level of less than 0.05 .

Table 5

Results of the correlation test of the fourth research hypothesis

\begin{tabular}{lcccc}
\hline & $\begin{array}{c}\text { Correlation } \\
\text { statistics }\end{array}$ & $\begin{array}{c}\text { Degrees of } \\
\text { freedom }\end{array}$ & $\begin{array}{c}\text { Significance } \\
\text { level }\end{array}$ & $\begin{array}{c}\text { Confirm or reject } \\
\text { the hypothesis }\end{array}$ \\
\hline $\begin{array}{l}\text { Employees' perception of } \\
\text { interactive justice and social capital }\end{array}$ & $0 / 674$ & 212 & $0 / 000$ & Confirm \\
\hline
\end{tabular}

The results of Table 5 show that there is a significant and positive relationship between employees' perceptions of interactive justice and social capital regarding a significance level of less than 0.05 .

Table 6

Results of the correlation test of the fifth research hypothesis

\begin{tabular}{lcccc}
\hline & $\begin{array}{c}\text { Correlation } \\
\text { statistics }\end{array}$ & $\begin{array}{c}\text { Degrees of } \\
\text { freedom }\end{array}$ & $\begin{array}{c}\text { Significance } \\
\text { level }\end{array}$ & $\begin{array}{c}\text { Confirm or reject } \\
\text { the hypothesis }\end{array}$ \\
\hline $\begin{array}{l}\text { Employees' perceptions of } \\
\text { information justice and social capital }\end{array}$ & $0 / 881$ & 212 & $0 / 000$ & Confirm \\
\hline
\end{tabular}

The results of Table 6 show that there is a significant and positive relationship between employees' perceptions of information justice and social capital regarding a significance level of less than 0.05 .

\section{Discussion and Conclusion}

The purpose of this study was to investigate the relationship between employees' perceptions of organizational justice and social capital in the National Tax Administration in the south of Tehran. The results showed that there was a positive and significant relationship between organizational justice and its components with social capital. The findings of this study are consistent with the studies by Siddiqui and Pouramini [22], Kheirandish and Jafarinia [23], Chavishni and Naghshbandi (2014)[24], and Buluc [25]. They showed that there was a positive and significant relationship between organizational justice and social capital.

It can be said that organizational justice is how rewards and punishments are distributed within a social group and have a significant impact on the organizational behavior of employees and determine why people react to unfair consequences, inappropriate processes and procedures, and unfair dealings. The sense of justice in
Hypothesis 4: There is a significant relationship between employees' perceptions of interactive justice and social capital.
Hypothesis 5: There is a significant relationship between employees' perception of information justice and social capital. the organization affects the attitudes, practices, and behaviors within the organization and affects the way the employees deal with external stakeholders, especially customers. In general, organizational justice can have ideal and desirable results in the workplace. Organizational justice is one of the most important ways to help organizations and provide an environment full of social capital and achieve essential achievements in this regard. It can be said that a positive perception of organizational justice can increase the individuals' social capital. People with higher social capital can also trust people from other groups and organizations. In addition to their broad political participation, they are members of various groups and associations and take steps to make organizational prestige and trust. Besides, to have a participatory spirit, these people try to establish informal relationships in the organization, which leads to empathy and teamwork between them. Finally, Baron and Greenberg believe that aggressive and dangerous behaviors increase when people feel treated unfairly in the organization. The perception of injustice in the workplace is one of the main factors influencing aggressive behaviors.

Give the relationship between distributive justice and social capital, it can be said that distributive justice is not limited to the fairness of payments but also 
includes a wide range of organizational consequences. Distributive justice is based on the principle of exchange. People compare what they do in exchange with what they receive. Employees' views and opinions on distributive justice have shown that people are satisfied with their salaries and are satisfied with the organization's schedule and the positions that exist in the organization for promotion. At the same time, the organization's employees are primarily satisfied with evaluating their performance, and the rewards and benefits received. Employees who are satisfied with the status of salaries and benefits received in the organization and consider the organization a suitable environment for their promotion use their efforts to further the organization's goals and interact and communicate with other colleagues for this purpose. The organization also needs such employees to achieve its short-term and long-term goals. Therefore, managers should try to increase it by considering distributive justice. In general, it can be said that simply providing rewards or providing the possibility of promotion and fair distribution procedures is not enough to increase employee commitment. However, the category of work and work environment, mutual respect and attention, employee participation in decisions, observance of justice and fairness in daily dealings, and evaluation of people's performance make them pay more attention to the goals and values of the organization.

Procedural justice is a concept that refers to the fairness of methods used to make decisions about how to distribute facilities. Given the relationship between procedural justice and social capital, it can be said that if employees believe they are effective in the organization and participate in the decisions made by the organization and when they are satisfied with the procedures and steps regarding their salaries, benefits, and performance, they increase the loyalty, commitment, motivation to work alongside other employees and perform the organizational tasks to advance the organization's goals. Therefore, managers must take steps to improve the status of procedural justice in the organization.

Justice is a relationship related to aspects of the manager's communication with his subordinates, such as politeness, honesty, and respect during the interaction. This type of justice is associated with cognitive, emotional, and behavioral reactions to the manager. Given the relationship between interactive justice and social capital, it can be said that when employees are satisfied with the attitude, relationships, and behavior in the organization, especially by managers, and find a positive view of the organization, they consider the organization as a ship that everyone should achieve a single goal. As a result, without coercion or direct order of the manager, they try to solve the organization's problems and advance its goals.
It should be paid attention to the factors that strengthen interpersonal justice, and efforts should be made to create a suitable atmosphere to increase these factors as much as possible. Therefore, if the organization's managers want to increase the efforts of employees towards organizational goals, they must understand the fairness of the payments and rewards given to employees.

In the relationship between information justice and social capital, it can be said that the observance of justice is one of the essential issues in any organization and is one of the concepts that all human beings consider good and should pay attention to it. Justice at the organizational level reflects perceived fairness of decisions about how resources and rewards are allocated and distributed, fair implementation of procedures and decisions, how management treats employees, and the communication process such as politeness, honesty, and respect. Information justice refers to the information and explanations given by decision-makers as to why they use particular procedures or why they distribute the consequences through a particular method, or whether the information is logical, honest, and timely. With this description, it can be said that research shows that people who have a positive perception of organizational justice are more committed to their organization and are less absent, and have excellent performance; they are better organizational citizens and are more satisfied.

This research, like other researches, has some limitations: lack of familiarity and awareness of some subjects about the importance and necessity of research, and spending much time distributing and receiving questionnaires.

According to the present study results, it is suggested to researchers that this study be done comparatively between men and women because the issue of organizational justice can be different in two groups of men and women. It is also suggested that this research be done to achieve a better and safer result in a larger community.

\section{References}

1. Taleghani M, Babaei R. Social capital management, human resource development strategy. Presented at the Second Human Resources Empowerment Conference, Heran, Iran Human Resources Empowerment Foundation. 2008.

2. Barati H, Arizi H, Nouri A. The simple and multiple relationship of organizational justice with job performance in Isfahan Steel Company. Bus Manag Perspect. 2009; 33.

3. Ahmadi AA, Faizabadi H. Investigating the relationship between social capital and improving organizational performance. J Publ Manag. 2011; 6(3). 
4. Bies RJ. Interactional (in) justice: The sacred and the profane. Advances in organizational justice, 89118. 2001.

5. Moorman RH. Relationship between organizational justice and organizational citizenship behaviors: Do fairness perceptions influence employee citizenship?. $J$ Appl Psychol. 1991; 76(6): 845.

6. Kidder DL. Restorative justice: Not "rights", but the right way to heal relationships at work. Int J Conflict Manag. 2007.

7. Aydin, I., \& Karaman-Kepenekci, Y. (2008). Principals' opinions of organisational justice in elementary schools in Turkey. Journal of Educational Administration.

8. Seyed Javadin R, Taheri Attar G, Farahi M. Understanding how the dimensions of organizational justice affect the various aspects of job and organizational satisfaction. Bus Manag. 2008; 1(1): 5570 .

9. AMIRKAFI, M., \& HASHEMINASAB, F. (2014). The effect of organizational justice, perceived organizational support and organizational trust onorganizational commitment. Journal of social issues of iran. 1(4). 33-62

10. Johnson S, Schnatterly K, Hill A. Board composition beyond independence: social capital, human capital, and demographics. J Manag. 2013; 39(1): 232-262.

11. Turkina E, Thi M, Thai T. Social capital, networks, trust and immigrant entrepreneurship: a cross-country analysis. J Enterp Comm. 2013; 7(2): 108-124.

12. Mostafaei N, Samadi M. Study of the relationship between managers' communication skills and perception of organizational justice with job satisfaction among employees of Sahand University of Technology in Tabriz. J Sociol Stud. 2015; 31.

13. Ghafori Vernosfadrani MR, Golparvar M. Examine the relationship between organizational justice and organizational commitment component of municipal employees. J Psychol Stud. 2009; 5(4): 1-20.

14. Lambert E. The impact of organizational justice on correctional staff. J Crim Justice, 2003; 31(2): 155-167.
15. Bies RJ, Tripp TM. Justice as rationality: a relational commitment: measurement issues. Icfai J Organ Behav. 1995; 5(4): 7-25.

16. Crow MS, Lee CB, Joo JJ. Organizational justice and organizational commitment among South Korean police officers: an investigation of job satisfaction as a mediator, policing. Int J Pol Strat Manag. 2012; 35(2): 402-423.

17. Jacobs, J. (1961). On the regulation mechanism of environmentally controlled allometry (heterauxesis) in cyclomorphic Daphnia. Physiological Zoology, 34(3), 202216.

18. Taylor M. Building social capital through rhetoric and public relations. Manag Comm Q. 2011; 25(3): 436454.

19. Coleman, J. S. (1988). Social capital in the creation of human capital. American journal of sociology, 94, S95S120.

20 Alguezaui, Salma., Filieri, Raffaele. (2010). investigating the role of social capital in innovation: sparse versus dense network. Journal of Knowledge Management, 14(6), 891-909.

21. Chen JS, Lauren AS. The speed of knowledge transfer within multinational enterprises: the role of social capital. Int J Comm Manag. 2011; 21(1): 46-62.

22. Siddiqui $R$, Pouramini $Z$. Investigating the relationship between organizational justice and social capital (Case study: Employees of Ardabil Tejarat Bank). J Mod Manag Eng. 2019; 7(1).

23. Kheirandish M, Jafari Nia S. The effect of organizational justice on the promotion of social capital through meritocracy in the organization. J Soc Capital Manag Univ Tebran. 2018; 5(2).

24. Chavishni, R, Nehbandi, M. The relationship between organizational justice and social capital of employees in Kurdistan Power Distribution Company. Social Capital Management.2014;1(2):247-264.

25. Buluc B. The relationship between academic staff's perceptions of organizational justice and organizational citizenship behaviors. Stud Psychol. 2015; $57(1)$ : 49.

\section{SJAMAO}

Copyright: (C) 2021 The Author(s); This is an open-access article distributed under the terms of the Creative Commons Attribution License (http://creativecommons.org/licenses/by/4.0), which permits unrestricted use, distribution, and reproduction in any medium, provided the original work is properly cited.

Citation: Hosseini SM. Investigating the Relationship Between Employees' Perceptions of Organizational Justice and Social Capital in The National Tax Administration in the South of Tehran Province. SJAMAO, 2021; 3(2):1-7.

https://doi.org/10.47176/sjamao.3.2.1 